\title{
PEMANFAATAN MOL (MIKROORGANISME LOKAL) DARI MATERI YANG TERSEDIA DI SEKITAR LINGKUNGAN
}

\author{
Oleh : \\ Roni Assafaat Hadi \\ 1 Jurusan Agroteknologi, Fakultas Pertanian, Universitas Winaya Mukti, \\ Jalan Raya Tanjungsari Km. 29 Bandung - Sumedang 45362, Jawa Barat - Indonesia \\ roni.assafaat.hadi@gmail.com, No HP : 085723800633
}

\begin{abstract}
Abstrak
MOL (Mikroorganisme Lokal) adalah kumpulan mikroorganisme yang biasa "diternakkan", fungsinya dalam konsep "zero waste" adalah untuk "starter" pembuatan kompos organik. MOL mengandung Azotobacter sp., Lactobacillus sp., ragi, bakteri fotosintetik dan jamur pengurai selulosa yang berfungsi dalam penguraian senyawa organik. Dengan MOL ini maka konsep pengomposan bisa selesai dalam waktu 3 mingguan. Bahan utama pembuatan MOL terdiri dari 3 jenis komponen, yaitu : Karbohidrat (Bisa dari Air cucian beras (Tajin), bisa dari nasi bekas (basi), bisa dari singkong, kentang, gandum. Yang paling sering memang dengan air tajin, Glukosa (Bisa dari gula merah bata diencerkan dengan air, bisa dari cairan gula pasir, bisa dari gula batu dicairkan, bisa dari air gula dan air kelapa, Sumber Bakteri (Bisa dari bahan sampah dapur yang mudah membusuk atau sayur kemarin yang telah basi. Bisa juga dari bahan lain misalnya keong sawah yang ditumbuk, buah-buahan yang busuk, bonggol pisang, dan eceng gondok dll, lalu bisa juga dari air kencing, atau apapun yang mengandung sumber bakterinya).Tinggal pilih bahan yang paling mudah didapat disekitar kita. Setelah bahan dipilih dari salah satu di atas, kemudian dimasukkan ke dalam drum plastik dan diberi air, hingga bahan tenggelam. Setelah 4 atau 5 hari MOL ini sudah bisa dipakai.

Selain untuk "starter" kompos, MOL bisa juga dipakai untuk "pupuk cair" dengan cara diencerkan terlebih dahulu, 1 bagian MOL dicampur 15 bagian air. Siramkan pada tanah di sekitar tanaman dan upayakan jangan mengenai batang tanaman.

Jadi bisa disimpulkan MOL itu semacam bakteri buatan sendiri (lokal) untuk menyuburkan tanah atau untuk menguraikan sampah organik menjadi kompos yang berguna seperti nutrisi (vitamin) bagi tanah agar tetap subur.
\end{abstract}

Kata Kunci : Mikroorganisme Lokal, Pembuatan MOL, Pupuk Cair Organik.

\begin{abstract}
MOL (Local Microorganisms) is a collection of microorganisms commonly "farmed", function in the concept of "zero waste" is for "starter" organic composting. MOL containing Azotobacter sp., Lactobacillus sp., Yeast, photosynthetic bacteria and cellulose decomposing fungi which function in the decomposition of organic compounds. With MOL is the concept of composting can be completed within 3 weeks. The main ingredient of making MOL consists of three types of components, namely: Carbohydrates (Can of Water washing rice (Tajin), may from former rice (casserole), can of cassava, potato, wheat. Most often it is the starch water, Glucose (Can of
\end{abstract}

Pemanfaatan Mol (Mikroorganisme Lokal)

RONI ASSAFAAT HADI

dari Materi yang Tersedia di Sekitar

Lingkungan 
red brick sugar diluted with water, can of liquid sugar, sugar cubes can of thawed, can of sugar water and coconut water, source of bacteria (Can be made from kitchen waste are easily decaying or vegetable that has been stale yesterday. It could also be of another material, for example snails pounded rice, rotten fruit, banana weevil, and water byacinth etc., then it could be from urine, or any source containing the bacteria. Just choose the most readily available materials around us. Once the material is selected from one of the above, then put in plastic drums and water, to sink materials. After 4 or 5 days MOL can already be used.

In addition to the "starter" compost, MOL can also be used to "liquid fertilizer" by way of first diluted, 1 part mixed with 15 parts of water MOL. Pour the soil around the plant and do not kick the stem of the plant.

So it can be concluded that some sort of bacteria MOL homemade (locally) to enrich the soil or to decompose organic waste into compost which is useful as nutrients (vitamins) for the soil to remain fertile.

Keywords : Local Microorganisms, Making MOL, Organic Liquid Fertilizer.

Pemanfaatan Mol (Mikroorganisme Lokal) 


\section{PENDAHULUAN}

Mikroorganisme merupakan jasad hidup yang mempunyai ukuran sangat kecil (Kusnadi, dkk, 2003). Setiap sel tunggal mikroorganisme memiliki kemampuan untuk melangsungkan aktivitas kehidupan antara lain dapat mengalami pertumbuhan, menghasilkan energy dan bereproduksi dengan sendirinya. Larutan MOL (Mikro Organisme Lokal) adalah larutan hasil fermentasi yang berbahan dasar dari berbagai sumber daya yang tersedia setempat baik dari tumbuhan maupun hewan. Larutan MOL mengandung unsur hara mikro dan makro dan juga mengandung bakteri yang berpotensi sebagai perombak bahan organik dalam tanah, perangsang pertumbuhan pada tanaman, dan sebagai agens pengendali hama dan penyakit tanaman.

Banyak yang menduga bahwa mikroorganisme membawa dampak yang merugikan bagi kehidupan hewan, tumbuhan, dan manusia, misalnya pada bidang mikrobiologi kedokteran dan fitopatologi banyak ditemukan mikroorganisme yang pathogen yang menyebabkan penyakit dengan sifat-sifat kehidupan yang khas. Meskipun demikian, masih banyak manfaat yang dapat diambil dari mikkroorganisme-mikroorganisme tersebut. Penggunaan mikroorganisme dapat diterapkan dalam berbagai bidang kehidupan, seperti bidang pertanian, kesehatan, dan lingkungan.

Dalam bidang pertanian, mikroorganisme dapat digunakan untuk peningkatan kesuburan tanah melalui fiksasi $\mathrm{N}_{2}$, siklus nutrient, dan peternakan hewan. Salah satunya dapat dimanfaatkan untuk pembuatan kompos. Mikroorganisme (bakteri pembusuk) ini dapat berinteraksi membantu proses pelapukan bahan-bahan organic seperti dedaunan, rumput, jerami, buah-buahan yang telah sangat matang, sisa- sisa ranting dan dahan, kotoran hewan dan lainnya. Adapun kelangsungan hidup mikroorganisme tersebut diukung oleh keadaan lingkungan yang basah dan lembab.

Di alam terbuka, kompos bisa terjadi dengan sendirinya, lewat proses alamiah. Namun, proses tersebut berlangsung lama sekali, dapat mencapai puluhan tahun, bahkan berabad-abad. Padahal kebutuhan akan tanah yang subur sudah mendesak. Oleh karenanya, proses tersebut perlu dipercepat dengan bantuan manusia dengan cara yang baik, proses mempercepat pemuatan kompos berlangsung wajar sehingga bisa diperoleh kompos yang berkualitas baik. Dengan demikian manusia tidak perlu menunggu puluhan tahun jika sewaktu-waktu kompos tersebut diperlukan.

Kompos merupakan pupuk yang sering diaplikasikan ke lahan, dan untuk membantu proses dekomposisi bahanbahan organic menjadi kompos, diperlukan bahan-bahan decomposer. Berbagai macam bahan-bahan decomposer banyak beredar di pasar (seperti EM4). Akan tetapi biaya yang dikeluarkan mahal. Pada dasarnya kompos yang berbahan dasar mikroorganisme mudah diproduksi sendiri, karena mikroorganisme-mikroorganisme yang berguna banyak terdapat di alam sekitar kita.

Proses pembuatan kompos ini salah satunya dapat menggunakan MOL (Mikro Organisme Lokal). Larutan MOL mengandung unsure hara makro dan mikro dan juga mengandung bakteri yang berpotensi sebagai perombak bahan organic, perangsang pertumbuhan dan sebagai agens pengendali hama dan penyakit tanaman.

Keunggulan penggunaan MOL yang paling utama adalah murah bahkan tanpa biaya Dengan memanfaatkan bahanbahan yang ada di sekitar.

Permasalahan yang diangkat dalam penelitian ini terutama hubungan dengan 
Pengelolaan Sumber Daya Alam Pertanian yaitu mengetahui dan mempelajari pengaruh pemberian aplikasi MOL sebagai decomposer dalam pembuatan kompos dari tanaman kacang-kacangan (legume).

Tujuan dari penelitian ini adalah untuk mengetahui pengaruh pemberian aplikasi MOL sebagai decomposer dalam pembuatan kompos dari tanaman kacangkacangan (legume).

Manfaat dari penelitian pemberian aplikasi MOL sebagai decomposer (bioaktivator) dalam pembuatan kompos dari tanaman kacang-kacangan, dan larutan MOL yang di ujikan diharapkan dapat sebagai pengembangan IPTEKS dalam efektivitas pemanfaatan pupuk sehingga meningkatkan ketersediaan unsure hara serta kecenderungan pemakaian pupuk anorganik dalam dosis yang berlebihan dapat dikurangi sehingga biaya usahatani dapat dikurangi karena memafaatkan bahanbahan organik yang berada di sekitar lingkungan.

Hipotesis dari penelitian ini yaitu terdapat pengaruh pemberian aplikasi MOL sebagai decomposer dalam pembuatan kompos dari tanaman kacang-kacangan (legume).

TINJAUAN PUSTAKA

\section{MOL (Mikro Organisme Lokal) dan Peranannya}

MOL adalah kumpulan mikro organisme yang bisa "diternakan", fungsinya dalam konsep "zero waste" adalah untuk "starter" pembuatan kompos organic. Dengan MOL ini maka konsep pengomposan bisa selesai dalam waktu 3 mingguan.

Larutan MOL (Mikro Organisme Lokal) adalah hasil dari fermentasi yang berbahan dasar dari sumberdaya yang tersedia setempat. Larutan MOL mengandung unsure hara makro dan mikro dan juga mengandung bakteri yang berpotensisebagai perombak bahan organic, perangsang pertumbuhan dan sebagai agens pengendali hama dan penyakit tanaman. Sehingga MOL dapat digunakan baik sebagai pendekomposer, pupuk hayati, dan sebagai pestisida organic terutama sebagai fungisida (Purwasasmita, 2009).

Peran MOL dalam kompos, selain sebagai penyuplai nutrisi juga berperan sebagai komponen bioreaktor yang bertugas menjaga proses tumbuh tanaman secara optimal. Fungsi dari bioreaktor sangatlah kompleks, fungsi yang telah teridentifikasi antara lain adalah penyuplai nutrisi melalui mekanisme eksudat, kontrol mikroba sesuai kebutuhan tanaman, menjaga stabilitas kondisi tanah menuju kondisi yang ideal bagi pertumbuhan tanaman, bahkan kontrol terhadap penyakit yang dapat menyerang tanaman (Purwasasmita, 2009). Informasi terkait pemanfaatan mikroorganisme lokal ini diperoleh dalam program pendampingan petani SLPTT (Sekolah Lapang Pengeloaan Tanaman Terpadu). MOL juga memiliki manfaat lain, yaitu :

1. Memperbaiki sifat fisik, kimia, dan biologis tanah

2. Menyediakan unsure hara yang dibutuhkan tanaman

3. Menyehatkan tanaman, meningkatkan produksi tanaman, dan menjaga kestabilan produksi

4. Menambah unsure hara tanah dengan cara disiramkan ke tanah, tanaman, atau disemprotkan ke daun.

5. Mempercepat pengomposan sampah organik atau kotoran hewan

\section{Kompos dan Manfaatnya bagi tanaman}

Pupuk kompos saat ini banyak dicari dan digunakan oleh petani baik untuk budidaya tanaman sayuran maupun untuk tanama padi, tetapi seringkali petani 
menganggap bahwa pupuk kompos hanya berasal dari kotoran hewan. Padahal bahan yang dapat digunakan sangat banyak dan tersedia dilingkungan sekitar seperti, daundaunan, jerami sisa sayuran dan buahbuahan serta sampah rumah tangga kecuali plastik.

Kompos adalah hasil penguraian parsial/tidak lengkap dari campuran bahan-bahan organic yang dapat dipercepat secara artificial oleh populasi berbagai macam mikroba dalam kondisi lingkungan yang hangat, lembab, dan aerobic atau anaerobic (Modifikasi dari J.H. Crawford, 2003), Sedangkan pengomposan adalah proses dimana bahan organic mengalami penguraian biologis, khususnya oleh mikroba-mikroba yang memanfaatkan bahan organic sebagai sumber energy. Membuat kompos adalah mengatur dan mengontrol prose alami tersebut agar kompos dapat terbentuk lebih cepat. Proses ini meliputi membuat campuran bahan yang seimbang, pemberian air yang cukup, mengatur aerasi, dan penambahan activator pengomposan.

Kompos merupakan bahan-bahan organik (sampah organic) yang telah mengalami proses pelapukan karena adanya interaksi antara mikroorganisme yang bekerja di dalamnya. Penggunaan kompos sangat baik karena dapat memberikan beberapa manfaat. Tanaman yang dipupuk dengan kompos juga cenderung lebih baik kualitasnya daripada tanaman yang dipupuk dengan pupuk kimia, misalnya hasil panen lebih tahan disimpa, lebih berat, lebih segar, dan lebih enak.

Kompos memiliki banyak manfaat yang ditinjau dari beberapa aspek :

A. Aspek Ekonomi :

1. Menghemat biaya untuk transportasi dan penimbunan limbah

2. Mengurangi volume /ukuran limbah
3. Memiliki nilai jual yang lebih tinggi dari pada bahan asalnya

B. Aspek Lingkungan

1. Mengurangi polusi udara karena pembakaran limbah dan pelepasan gas metana dari sampah organic yang membusuk akibat bakteri metanogen di tempat pembuangan sampah

2. Mengurangi kebutuhan lahan untuk penimbunan

C. Aspek bagi tanah/tanaman :

1. Meningkatkan kesuburan tanah

2. Memperbaiki struktur dan karakteristik tanah

3. Meningkatkan kapasitas penyerapan air oleh tanah

4. Meningkatkan aktivitas mikroba tanah

5. Menigkatkan kualitas hasil panen (rasa, nilai gizi, dan jumlah panen)

6. Menyediakan hormon dan vitamin bagi tanaman

7. Menekan retensi/ketersediaan hara di dalam tanah

Faktor yang mempengaruhi proses pengomposan

Setiap organisme pendegradasi bahan organik membutuhkan kondisi lingkungan dan bahan yang berbeda-beda. Apabila kondisinya sesuai, maka dekomposer tersebut akan bekerja giat untuk mendekomposisi limbah padat organik. Apabila kondisinya kurang sesuai atau tidak sesuai, maka organisme tersebut akan dorman, pindah ke tempat lain, atau bahkan mati. Menciptakan kondisi yang optimum untuk proses pengomposan sangat menentukan keberhasilan proses pengomposan itu sendiri. Faktor-faktor yang mempengaruhi proses pengomposan antara lain :

- Rasio C/N : Rasio C/N yang efektif untuk proses pengomposan berkisar antara 30:1 Hingga 40:1. Mikroba 
memecah senyawa $C$ sebagai sumber energi dan menggunakan $\mathrm{N}$ untuk sintesis protein. Pada rasio $\mathrm{C} / \mathrm{N}$ diantara 30s/d 40 mikroba mendapatkan cukup C untuk energy dan $\mathrm{N}$ untuk sintesis protein. Apabila rasio $\mathrm{C} / \mathrm{N}$ terlalu tinggi, mikroba akan kekurangan $\mathrm{N}$ untuk sintesis protein sehingga dekomposisi berjalan lambat. Umumnya, masalah utama pengomposan adalah pada rasio $\mathrm{C} / \mathrm{N}$ yang tinggi, terutama jika bahan utamanya adalah bahan yang mengandung kadar kayu tinggi (sisa gergaji kayu, ranting, ampas tebu, dsb). Untuk menurunkan rasio $\mathrm{C} / \mathrm{N}$ diperlukan perlakuan khusus, misalnya menambahkan mikroorganisme selulotik (Toharisman, 1991) atau dengan menambhakan kotoran hewan karena kotoran hewan mengandung banyak senyawa nitrogen.

- Ukuran Partikel : Aktivitas Mikroba berada diantara permukaan area dan udara. Permukaan area yang lebih luas akan meningkatkan kontak antara mikroba dengan bahan dan proses dekomposisi akan berjalan lebih cepat. Ukuran partikel juga menentukan besarnya ruang antar bahan (porositas). Untuk menentukan luas permukaan dapat dilakukan dengan memperkecil ukuran partikel bahan tersebut.

- Aerasi : Pengomposan yang cepat dapat terjadi dalam kondidi yang cukup oksigen (aerob). Aerasi secara alami akan terjadi pada saat terjadi peningkatan suhu yang menyebabkan udara hangat keluar dan udara yang dingin masuk ke dalam tumpukan kompos. Aerasi ditentukan oleh porositas dan kandungan air bahan (kelembaban), Apabila aerasi terhambat, maka akan terjadi proses anaerob yang akan menghasilkan bau yang tidak sedap. Aerasi dapat ditingkatkan dengan melakukan pembalikan atau mengalirkan udara di dalam tumpukan kompos.

- Porositas : Porositas adalah ruang diantara partikel di dalam tumpukan kompos. Porositas dihitung dengan mengukur volume rongga dibagi dengan volume total. Rongga-rongga ini akan diisi oleh air dan udara. Udara akan mensuplay oksigen untuk proses pengomposan. Apabila rongga dijenuhi oleh air, maka pasokan oksigen akan berkurang dan proses pengomposan juga akan terganggu.

- Kelembaban (Moisture content) : Kelembaban memegang peranan yang sangat penting dalam proses metabolisme mikroba dan secara tidak langsung berpengaruh pada suplay oksigen. Mikroorganisme dapat memanfaatkan bahan organic apabila bahan organic tersebut larut di dalam air. Kelembaban $40-60 \%$ adalah kisaran optimum untuk meabolisme mikroba. Apabila kelembaban dibawah $40 \%$, aktivitas mikroba akan mengalami penurunan dan akan lebih rendah lagi pada kelembaban 15\%. Apabila kelembaban lebih besar dari 60\%, hara akan tercuci, volume udara berkurang, akibatnya aktivitas mikroba akan menurun dan akan terjadi fermentasi anaerobik yang menimbulkan bau tidak sedap.

- Temperatur/suhu : Panas dihasilkan dari aktivitas mikroba. Ada hubungan langsung antara peningkatan suhu dengan konsumsi oksigen. Semakin tinggi temperature akan semakin banyak konsumsi oksigen akan semakin cepat pula proses dekomposisi. Peningkatan suhu dapat terjadi dengan cepat pada tumpukan kompos. Temperatur yang berkisar antara $30-60^{\circ} \mathrm{C}$ akan membunuh sebagian mikroba dan hanya mikroba thermofilik saja yang 
akan tetap bertahan hidup. Suhu yang tinggi juga akan membunuh mikrobamikroba pathogen tanaman dan benihbenih gulma.

- $\quad \mathbf{p H}$ : Proses pengomposan dapat terjadi pada kisaran $\mathrm{pH}$ yang lebar. $\mathrm{pH}$ yang optimum untuk proses pengomposan berkisar antara 6,5 sampai 7,5. $\mathrm{pH}$ kotoran temak umumnya berkisar antara 6,8 hingga 7,4. Proses pengomposan sendiri akan menyebabkan perubahan pada bahan organic dan $\mathrm{pH}$ bahan itu sendiri. Sebagai contoh, proses pelepasan asam, secara temporer atau local, akan menyebabkan penurunan $\mathrm{pH}$ (pengasaman), sedangkan produksi ammonia dari senyawa-senyawa yang mengandung nitrogen akan meningkatkan $\mathrm{pH}$ pada fase-fase awal pengomposan. $\mathrm{pH}$ kompos yang sudah matang biasanya mendekati netral.

- Kandungan Hara : Kandungan P dan $\mathrm{K}$ juga penting dalam proses pengomposan dan biasanya terdapat di dalam kompos-kompos dari peternakan. Hara ini akan dimanfaatkan oleh mikroba selama proses pengomposan.

- Kandungan Bahan Berbahaya : Beberapa bahan organik mungkin mengandung bahan-bahan yang berbahaya bagi kehidupan mikroba. Logam-logam berat seperti $\mathrm{Mg}, \mathrm{Cu}, \mathrm{Zn}$, $\mathrm{Ni}$, Cr adalah beberapa bahan yang termasuk kategori ini. Logam-logam berat akan mengalami imobilisasi selama proses pengomposan.

- Lama Pengomposan : Lama waktu pengomposan tergantung pada karakteristik bahan yang dikomposkan. Metode pengomposan yang dipergunakan dena dengan atau tanpa penambahan activator pengomposan. Secara alami pengomposan akan berlangsung dalam waktu beberapa minggu sampai 2 tahun hingga kompos benar-benar matang.

\section{Interaksi antara bakteri Rhizobium dengan akar kacang-kacangan}

Tanaman kacang-kacangan seperti buncis, kedelai, akarnya memiliki bintilbintil berisi bakteri yang mampu menambat nitrogen udara, sehingga nitrogen tanah yang telah diserap tanaman dapat diganti. Simbiosis antara tanaman dan bakteri saling menguntungkan untuk kedua pihak. Bakteri mendapatkan zat hara yang kaya energi dari tanaman inang sedangkan tanaman inang mendapatkan senyawa nitrogen dari bakteri untuk melangsungkan kehidupannya. Bakteri penambat nitrogen yang terdapat didalam akar kacang-kacangan adalah jenis bakteri Rhizobium. Bakteri ini masuk melalui rambut-rambut akar dan menetap dalam akar tersebut dan membentuk bintil pada akar yang bersifat khas pada kacangkacangan. Bakteri dalam genus Rhizobium merupakan bakteri gram negatif, berbentuk bulat memanjang, yang secara normal mampu memfiksasi nitrogen dari atmosfer. Umumnya bakteri ini ditemukan pada nodul akar tanaman leguminosae. 


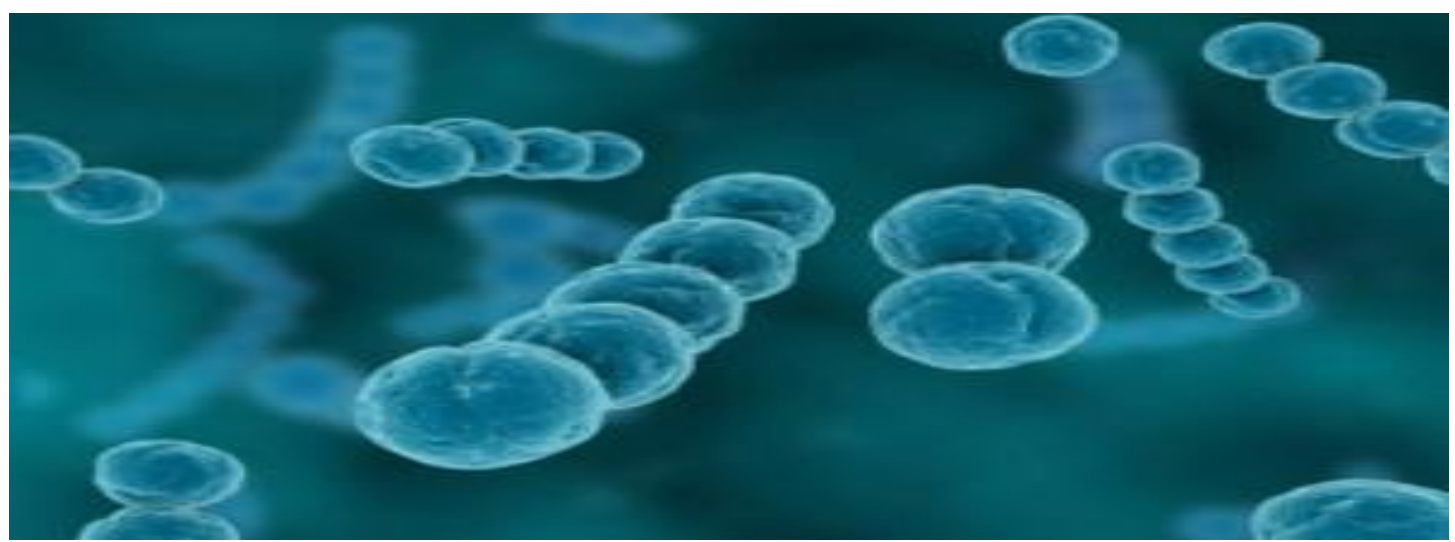

Gambar 1. Bakteri Rhizobium.

Rhizobium berasal dari dua kata yaitu Rhizo yang artinya akar dan bios yang berarti hidup. Rhizobium adalah bakteri yang bersifat aerob, bentuk batang, koloninya berwarna putih berbentuk sirkular, merupakan penambat nitrogen yang hidup di dalam tanah dan berasosiasi simbiotik dengan sel akar legume, bersifat host spesifik satu spesies Rhizobium cenderung membentuk nodul akar pada satu spesies tanaman legume saja. Bakteri Rhizobium adalah organotrof, tidak berspora, dan pleomorf. Bakteri rhizobium mudah tumbuh dalam medium pembiakan organik khususnya yang mengandung ragi atau kentang. Pada suhu kamar dan $\mathrm{Ph} \mathrm{7,0} \mathrm{-} \mathrm{7,2.}$ Morfologi Rhizobium dikenal sebagai bakteroid. Rhizobium menginfeksi akar leguminoceae melalui ujung-ujung bulu akar yang tidak berselulose, karena bakteri Rhizobium tidak dapat menghidrolisis selulose. Interaksi bakteri Rhizobium dengan akar kacangkacangan dibahas dalam ilmu tersendiri yang dinamakan Rhizobiologi. Interaksi ini mengakibatkan terbentuknya nodul akar pada tumbuhan kacang-kacangan.
Terdapat beberapa spesies Rhizobium dan tanaman simbiosisnya.

\section{METODE PENELITIAN}

\section{Waktu dan Tempat Pelaksanaan}

Percobaan pembuatan kompos yang diaplikasikan dengan MOL bertempat di rumah kompos, dan pembuatan MOL dilakukan di laboratorium Ilmu Tanah Fakultas Pertanian Universitas Winaya Mukti Bandung - Jawa Barat. Percobaan ini dilaksanakan pada tanggal 10 April sampai 30 Mei 2014.

\section{Alat dan Bahan}

Alat dan Bahan yang digunakan dalam pembuatan Mikro Organisme Lokal : Alat yang digunakan dalam pembuatan Mikro Organisme Lokal, yaitu pisau, blender, selang, batang pengaduk, saringan, wadah, botol dan beaker glass $1000 \mathrm{ml}$, sedangkan bahan yang digunakan dalam pembuatan kompos, yaitu pepaya 500 gram, pisang 500 gram, gula merah 1000 gram, air tajin, dan air $4000 \mathrm{ml}$.

Alat dan Bahan yang digunakan dalam pembuatan Kompos :

Alat yang digunakan dalam pembuatan kompos, yaitu cangkul, garpu besi, kayu/bamboo, plastic, karung goni, timbangan, dan pisau sedangkan bahan yang 
digunakan dalam pembuatan kompos, yaitu jerami padi, serasah tanaman kacangkacangan yang sudah di kering anginkan, dan MOL.

\section{Cara Kerja}

Adapun cara pembuatan MOL adalah dengan cara-cara seperti berikut :

1. Kita campurkan air yang mengandung karbohidrat dengan air yang mengandung glukosa dengan perbandingan volume kirakira $1: 1$ (memang disini takaran pastinya tidak jelas, karena petani akan lebih mudah ingat apabila penyampaiannya sederhana saja, tidak rumit-rumit). Campurkan dengan air tajin dan larutan air gula merah sebagai sumber makanan bagi mikroorganisme.

2. Lalu aduk merata dan campurkan dengan sumber bakteri misalnya pepaya, pisang, atau buah-buahan lain yang telah dihaluskan.

3. Aduk dan tutup wadah dengan botol plastik yang dilubangi yang disumbat dengan selang (apapun yang bisa menutupi wadah dengan catatan udara dapat masuk, tapi lalat tidak bisa masuk).

4. Lalu diamkan dan simpan selama kurang lebih 5 - 7 hari.

5. Lakukan pengecekan sampai mengeluarkan bau seperti hasil fermentasi (misal bau tape).

6. Jika sudah ada bau, berarti sudah jadi MOL-nya dan siap untuk digunakan.

Adapun cara pembuatan
kompos adalah dengan cara-cara seperti berikut :

1. Pertama-tama siapkn larutan MOL yang sudah dibuat.

2. Bahan jerami padi dan serasah tanaman kacang-kacangan dikeringanginkan selama satu hari kemudian dicampur merata di atas lantai yang kering.

3. Selanjutnya bahan disiram larutan MOL secara perlahan dan bertahap sehingga terbentuk adonan. Adonan yang terbentuk jika dikepal dengan tangan, maka tidak ada air yang keluar dari adonan. Begitu juga bila kepalan dilepaskan maka adonan kembali mengembang (kandungan air sekitar $30 \%)$.

4. Adonan selanjutnya dibuat menjadi sebuah gundukan setinggi $15-20 \mathrm{~cm}$. Gundukan selanjutnya ditutup dengan karung goni selama 3-4 hari. Selama dalam proses, suhu bahan dipertahankan antara $40-50^{\circ} \mathrm{C}$. Jika suhu bahan melebihi $50^{\circ} \mathrm{C}$, maka karung penutup dibuka dan bahan adonan dibolak-balik dan selanjutnya gundukan ditutup kembali.

5. Setelah empat hari karung goni dapat dibuka. Pembuatan bokashi dikatakan berhasil jika bahan bokashi terfermentasi dengan baik. Ciri-cirinya adalah bokashi akan ditumbuhi oleh jamur yang berwarna putih dan aromanya sedap. Sedangkan jika dihasilkan bokashi yang berbau busuk, maka pembuatan bokashi gagal.

6. Bokashi yang sudah jadi sebaiknya langsung digunakan. Jika bokashi ingin disimpan terlebih dahulu, maka bokashi harus dikeringkan terlebih dahulu dengan cara mengangin-anginkan di atas lantai hingga kering. Setelah kering bokashi dapat dikemas di dalam kantung plastik.

\section{HASIL PENELITIAN}

\section{MOL}

Setelah beberapa hari pengamatan, terjadi perubahan yang signifikan yaitu terjadinya proses yang ditandai dengan perubahan bau, dari yang mulanya berbau 
busuk berubah menjadi berbau tape/alhokol. Hal ini menandakan telah terjadi proses fermentasi secara sempurna, karena adanya aktivitas mikroorganisme yang ada pada sumber bakteri tersebut.

\section{KOMPOS}

Setelah beberapa hari proses pembuatan kompos, terjadi perubahan warna pada tanaman kacang-kacangan (legume) dari berwarna hijau menjadi coklat kehitaman dan jerami padi dari berwarna kuning menjadi coklat kehitaman. Kemudian dilihat dari bentuk fisik tanaman kacang-kacangan (legume) dan jerami padi yang mulanya kasar, berubah menjadi agak halus. Selain itu juga terjadi perubahan bau yang semulanya berbau busuk karena campuran bahan-bahan tersebut menjadi berbau masam. Hal ini juga disebabkan oleh adanya fermentasi yang sempurna.

\section{PEMBAHASAN}

MOL adalah kumpulan mikro organisme yang bisa "diternakkan", fungsinya dalam konsep "zero waste" adalah untuk "starter" pembuatan kompos organik. Dengan MOL ini maka konsep pengomposan bisa selesai dalam waktu 3 mingguan.

Selain untuk "starter" kompos, MOL bisa juga dipakai untuk "pupuk cair" dengan cara diencerkan terlebih dahulu, 1 bagian MOL dicampur 15 bagian air. Siramkan pada tanah di sekitar tanaman. Upayakan jangan mengenai batang tanaman. Untuk "anggrek"? Karena anggrek ini tumbuh di pakis dan akarnya menonjol, saya tidak menyarankan dengan pupuk cair MOL ini. Nanti pakisnya di makan MOL dan timbul panas yang bisa mematikan anggrek. Jadi baiknya untuk tanaman yang tumbuh di tanah saja, dan tanahnya yang disiram MOL encer.
Keunggulan penggunaan MOL yang paling utama adalah murah bahkan tanpa biaya. Dengan memanfaatkan bahan-bahan yang ada di sekitar, petani dapat kreatif membuat MOL dari bahan-bahan seperti buahbuahan busuk (pisang, pepaya, mangga, dan lain-lain), rebung bambu, pucuk tanaman merambat, tulang ikan, keong, urine sapi, bahkan sampai urine manusia, darah hewan, bangkai hewan, air cucian beras, dan sisa makanan. Menurut Amalia (2008), cara membuat MOL itu mudah, semua yang ada di sekitar kita dapat dipakai, semua bahan dicampur dengan larutan yang mengandung glukosa seperti air nira, air gula, atau air kelapa. Lalu ditutup dengan kertas, dibiarkan sampai 7 hari. Setelah itu dipakai untuk menyemprot ke sawah. Menurut Hadinata (2008), secara terperinci bahan utama dalam MOL terdiri dari 3 jenis komponen antara lain: Karbohidrat: air cucian beras (Tajin), nasi bekas (basi), singkong, kentang, gandum. Yang paling sering digunakan adalah dengan air tajin.

Glukosa: dari gula merah diencerkan dengan air, cairan gula pasir, gula batu dicairkan, air gula, dan air kelapa. Sumber Bakteri: keong mas, kulit buahbuahan misalnya tomat, pepaya, dan sebagainya, air kencing, atau apapun yang mengandung sumber bakteri.

Di dalam timbunan bahan-bahan organic pada pembuatan kompos, terjadi aneka perubahan hayati yang dilakukan oleh mikroba. Akibat perubahan tersebut, berat dan isi bahan kompos menjadi sangat berkurang. Sebagian besar senyawa yang ada di dalam kompos tersebut akan menghilang mengusp ke udara. Kadar senyawa $\mathrm{N}$ yang larut akan meningkat. Dalam pengomposan, kadar abu dan humus makin meningkat. Pada perubahan selanjutnya (diakhiri pembuatan kompos), akan diperoleh bahan yang berwarna coklat kehitaman. Bahan 
dengan kondisi seperti itu sedah siap digunakan sebagai pupuk.

Beberapa masalah yang dihadapi saat pembuatan kompos secara anaerob dalam plastijk. Yaitu :

1. Bau kompos yang busuk dan berbau fermentasi

2. Jika plastik bocor maka air akan masuk dan berceceran dan menimbulkan bau serta mengundang lalat, akhirnya banyak larva yang berkmbangbiak di dalamnya.

Dari percoban yang telah dilakukan yaitu telah berhasil membuat MOL (Mikro Organisme Lokal). MOL dikatakan berhasil jika telah memenuhi cirri-ciri sebagai berikut:

1. Bahan-bahan yang digunakan untuk membuat MOL hancur terdekomposisi oleh mikroba

2. Pada awal pembuatan MOL berbau sangat menyengat/ berbau tidak sedap. Namun saat MOL matang baunya tidak lagi menyengat tapi berbau masam/berbau fermentasi.

3. Tidak terdapat belatung didalamnya

4. MOL nya tidak sekeruh saat pertama kali di buat

Menurut Kurnia (2003), telah melakukan analisis atas sampel MOL sampah dapur. MOL sampah dapur mengandung pseudomonas, aspergilus sp, dan lactobacillus sp. Sementara itu, Hersanti (2007) mengisolasi bakteri dari berbagai larutan MOL. Bakteri yang berhasil diisolasi ada 19 isolat terdiri atas 3 isolat dari MOL daun cebreng, 1 isolat dari MOL pucuk waluh, 7 isolat dari MOL berenuk, 1 isolat dari NOL rebung, 3 isolat dari MOL bonggol pisang, 4 isolat dari MOL pisang. Karakterisik isolat bakteri dilakukan dengan mengamati morfologi koloni, yaitu warna, bentuk, permukaan, dan tepi koloni. Morfologi koloni 19 isolat bakteri diperoleh pada media nutrien agar. Berdasarkan gagasan yang diajukan penulis terkait pemberdayaan Mikro Organisme Lokal (MOL) di kalangan petani ada beberapa pihak yang dapat membantu mengimplementasikan gagasan yang diajukan tersebut antara lain :

1. Peneliti (Universitas) : Hal ini menarik untuk diteliti terkait jenis mikroorganisme apa saja yang terdapat dalam masing-masing bahan sumber MOL (Mikro Organisme Lokal) selain pustaka yang sudah diketahui. Dengan adanya penelitian tersebut sehingga akan diketahui manfaat yang lebih spesifik dari masing-masing sumber MOL karena sudah diketahui jenis mikroorganisme yang terkandung di dalamnya.

2. Dinas Pertanian : diharapkan Dinas Pertanian mampu membuat kebijakan untuk para petani terkait pemberdayaan pupuk organik secara mandiri melalui program-program sekolah lapang yang sudah dibiayai pemerintah. Hal ini sangat diperlukan sebagai upaya menciptakan kemandirian petani, revitalisasi lahan pertanian, serta mempopulerkan pertanian organik sehingga para petani dapat memanfaatkan bahan-bahan di sekitar mereka untuk membuat pupuk dan dekomposer.

\section{KESIMPULAN DAN SARAN}

\section{Kesimpulan}

MOL (Mikroorganisme Lokal) adalah kumpulan mikroorganisme yang biasa "diternakkan", fungsinya dalam konsep "zero waste" adalah untuk "starter" pembuatan kompos organik. MOL mengandung Azotobacter sp., Lactobacillus sp., ragi, bakteri fotosintetik dan jamur pengurai selulosa yang berfungsi dalam penguraian senyawa organik. Dengan MOL ini maka konsep pengomposan bisa selesai dalam waktu 3 mingguan. Bahan utama 
pembuatan MOL terdiri dari 3 jenis komponen, yaitu : Karbohidrat (Bisa dari Air cucian beras (Tajin), bisa dari nasi bekas (basi), bisa dari singkong, kentang, gandum. Yang paling sering memang dengan air tajin, Glukosa (Bisa dari gula merah bata diencerkan dengan air, bisa dari cairan gula pasir, bisa dari gula batu dicairkan, bisa dari air gula dan air kelapa, Sumber Bakteri (Bisa dari bahan sampah dapur yang mudah membusuk atau sayur kemarin yang telah basi. Bisa juga dari bahan lain misalnya keong sawah yang ditumbuk, buah-buahan yang busuk, bonggol pisang, dan eceng gondok dll, lalu bisa juga dari air kencing, atau apapun yang mengandung sumber bakterinya).Tinggal pilih bahan yang paling mudah didapat disekitar kita. Setelah bahan dipilih dari salah satu di atas, kemudian dimasukkan ke dalam drum plastik dan diberi air, hingga bahan tenggelam. Setelah 4 atau 5 hari MOL ini sudah bisa dipakai. Selain untuk "starter" kompos, MOL bisa juga dipakai untuk "pupuk cair" dengan cara diencerkan terlebih dahulu, 1 bagian MOL dicampur 15 bagian air. Siramkan pada tanah di sekitar tanaman dan upayakan jangan mengenai batang tanaman. Jadi bisa disimpulkan MOL itu semacam bakteri buatan sendiri (lokal) untuk menyuburkan tanah atau untuk menguraikan sampah organik menjadi kompos yang berguna seperti nutrisi (vitamin) bagi tanah agar tetap subur.

\section{Saran}

Dari hasil percobaan ini, dapat di tarik saran yaitu karena banyaknya manfaat yang diperoleh dari pembuatan dan penggunaan MOL (Mikro Organisme Lokal) serta kompos, antara lain : sederhana dan mudah untuk di buat, waktu relative singkat, murah, pupuk organic yang dihasilkan mengandung unsure kompleks dan mikroba bermanfaat, ramah lingkungan, memperbaiki kualitas tanah, produk pertanian aman dikonsumsi.

\section{DAFTAR PUSTAKA}

Djaja, Willyan. 2010. Langkah Jitu Membuat Kompos dari Kotoran Ternak \& Sampah. PT. Agromedia Pustaka. Jakarta. http://id.wikipedia.org/wiki/Kom pos.

Kariman, Lakbok. 2008. Pembuatan starter/MOL (Mikro Organisme Lokal) Oleb Petani. http://Organicfield.blogspot.com.

Murbandono, L. Membuat Kompos (Jakarta : Penebar Swadaya, 2009).

Sobirin. 2010. MOL tapai atau MOL Peuyeum Lebih Bersih http://clearwaste.blogspot.com/dia kses.

Syaifudin, Achmad. Dkk. Pemberdayaan Mikroorganisme Lokal Sebagai Upaya Peningkatan Kemandirian Petani. http://le3n1.blog.uns.ac.id/files/20 10/05/pemberdayaanmikroorganisme-lokal-sebagaiupava-peningkatan-kemandirianpetani.pdf 